\title{
The diversity of plants used for the traditional dish sarma in Turkey: nature, garden and traditional cuisine in the modern era
}

\author{
Yunus Dogan ${ }^{1}$, Anely Nedelcheva ${ }^{2 *}$, Andrea Pieroni ${ }^{3}$ \\ ${ }^{1}$ Buca Faculty of Education, Dokuz Eylul University, Buca, Izmir, Turkey, ${ }^{2}$ Department of Botany, Sofia University "St. Kliment Ohridski”, Sofia, \\ Bulgaria, ${ }^{3}$ University of Gastronomic Sciences, Bra, Pollenzo, Italy
}

\section{A B S TR A C T}

\begin{abstract}
The selection of leaves for the traditional dish sarma is the result of human experience and observation, and the transfer of traditional knowledge in regions differing in the richness of their species. The purpose of this study is to update the list of leaf vegetable plants that are used to prepare the traditional dish sarma and to analyse the biodiversity of the species used and their status in the Turkish flora. Seventy-three taxa whose leaves are used to prepare sarma in Turkey are reported. The prevalent species are those of Rumex (11), Salvia (5), Beta and Malva (4), Alcea, Arum, Brassica, Morus, and Plantago (3). Wild herbaceous plants (69.5\%) dominate. Trees (8) and shrubs (2) mostly belong to the Rosaceae, Moraceae, Betulaceae and Malvaceae. Grapevine and cabbage predominate, together with beet, dock, sorrel, horseradish, European lime tree, bean, and spinach. The use of leaves of three endemics was recorded: Centaurea haradjianii, Rumex gracilescens, and Rumex olympicus. Some toxic plants are used following preliminary treatment, including those of Arum, Convolvulus, Tussilago and Smilax species. Colocasia esculenta is a novel sarma plant that has been used in cuisine in the last decade, following its introduction to Turkey.
\end{abstract}

Keywords: Edible leaf; Ethnobotany; Sarma; Traditional knowledge; Turkey

\section{INTRODUCTION}

Since ancient times, plants have been variously used by humans for food, as dyes, and for ornamental and medicinal purposes. During the last decade, this relationship between people and the plants growing in their environment, in both a historical and socio-cultural context, has been the subject of many ethnobotanical studies in Turkey (Dogan et al., 2003; Dogan et al., 2004; Simsek et al., 2004; Dogan et al., 2008; Ugulu et al., 2009; Nedelcheva et al., 2011; Dogan and Ugulu, 2013). A large number of these studies relate to the use of wild plants as food (Ertug, 2004; Dogan et al., 2004, Ozbucak et al., 2006; Kargioglu et al., 2010; Dogan, 2012), including wild edible plants sold on the open market (Dogan et al., 2013; Dogan and Nedelcheva, 2015).

These studies clearly show that widely used cultivated plants that are consumed as vegetables and fruit in Turkey include many wild plants, many of which have been used as salad and vegetable dishes in traditional recipes. An important component of Turkish cuisine inherited from the Ottomans consists of sarmas and dolmas. Dolma consists of stuffed or dried fruit and root vegetables, whereas sarma, which means "wrapping" in Turkish, consists of rolling vegetable leaves around the ingredients. Dolmas and sarmas are prepared either with olive oil (with rice or bulgur stuffing with fresh or dried herbs and seasoning and often served hot with yogurt), or with meat (prepared with minced lamb and veal mixed with rice and seasoned with fresh or dried herbs). Additionally, a meatless, socalled pseudo-dolma (yalancr dolma) is prepared with rice, onion, currants and pine nuts (Basaran, 2009). In Turkish cuisine, the filling ingredients might include pine kernels (Pinus pinea), black corinth (Vitis vinifera), blackcurrants (Ribes nigrum), and even mastic (resin of Pistacia lentiscus); an old tradition in Turkey was also to add sour cherries to the filling.

Sarma represents an important part of Ottoman cuisine, in which the term dolma is occasionally used to mean sarma,

\footnotetext{
${ }^{*}$ Corresponding author:

Anely Nedelcheva, Department of Botany, Sofia University “St. Kliment Ohridski”, 1164 Sofia, Bulgaria. E-mail: aneli_nedelcheva@yahoo.com

Received: 18 September 2016; $\quad$ Revised: 14 April 2017; $\quad$ Accepted: 30 April 2017; Published Online: 15 May 2017
} 
especially for grapevine leaf-based sarma. However, it is more correct to refer to dolma only in relation to stuffed vegetables (pepper, eggplant, zucchini, tomato, onion, potato, artichoke, okra and celery). The most widely known dolmas and sarmas worldwide is sarma, which is prepared with olive oil and grapevine leaves (yaprak sarmasi). However, grapevine-leaf sarma is known as "dolma" in many parts of the world (Basaran, 2009). Sarma represents one of the most widely encountered feasting dishes of Ottoman and Turkish cuisine (Dogan et al., 2015).

Sarma is used in everyday language and in a much broader sense to refer to the form and method of prepararing thin wraps. Tütün sarma is the name given to some tobacco wrapping products.

Owing to an increased interest in food ethnobotany, research has been conducted in Turkey and the Balkans (Bosnia, Bulgaria, Macedonia, Greece, Albania, in the Balkan areas of Croatia and Romania) into traditional knowledge (TK) about plants that are used to prepare sarma (Dogan et al., 2015). This study reviews the species used (taxa), and focuses on the importance of plant leaves and folk botanical knowledge regarding their use, both in the past and today. Eighty-seven taxa were found to represent the Turkish and Balkan sarma plant heritage. Turkey retains approximately half the entire sarma plant biodiversity recorded in the countries listed above, thus confirming the strong link between this culinary preparation and the Ottoman cuisine of the last four centuries. The results also demonstrate the extremely dynamic and changeable nature of folk ethnobotanical practices. The richness of the species and preservation of TK today justify a closer survey of the ethnobotany of this collection of taxa and its analysis based on plant biodiversity and the various impact factors that have resulted from the expansion of modern society.

Thus, the purpose of this study was to update the list of leaf vegetable plants that are used to prepare the traditional dish sarma and to analyse the biodiversity of these species and their status in the Turkish flora.

\section{MATERIALS AND METHODS}

\section{Study site and traditional cuisine}

Turkey has the largest coastal area of all Mediterranean countries and due to its climate and geographical position, possesses an extraordinarily rich flora, with more than 10,000 taxa. One-third of Turkey's plant taxa is endemic (Dogan, 2012).

Turkish cuisine is mostly based on Ottoman cuisine, which is influenced by Chinese, Iranian, Byzantine, Arab,
European and Mediterranean cuisines. Although it contains many contributions, Ottoman cuisine, in essence, is based on Turkish eating habits (Fragner, 1994; Savkay, 2000; Bilgin, 2014).

Even though vegetables entered Turkish cuisine relatively late, Ottoman cuisine was very rich in terms of vegetable dishes. Vegetables, which are important in the nourishment of the poor, were cheap in the capital when in season. Vegetables were consumed in great quantities, both by the public and the Palace. Amongst the vegetables purchased were spinach, cabbage, celery, beet, leek, chard, parsley, broad bean, pumpkin, carrot, cucumber, eggplant and vine leaves for sarma with meat. Chief among the Turkish cuisine inherited from the Ottomans are sarmas and dolmas (Yerasimos, 2002).

\section{Data collection \\ Field data collection}

The study was conducted during the undertaking of ethnobotanical field studies in Western Anatolia (Izmir and Manisa), Central Anatolia (Ankara and Eskisehir), Black Sea (Duzce); Eastern Anatolia (Malatya) and South Anatolia (Adana and Antalya) regions, and also during several ad hoc investigations by the authors between 2011 and 2015. Data were collected by means of semistructured interviews. A total of 47 women $(59 \%)$ and 32 men $(41 \%)$ were interviewed. The informants were divided into three age groups (i) 35-50, (ii) 51-60 and (iii) 61-83 years old. Most of the informants belonged to the age group 64-73 years.

Informants were asked to mention all plants whose leaves were used as wrapping material for preparing homemade sarma. Informants did this by showing fresh plants directly in the field, or parts thereof, as well as leaves that had been dried or preserved in various ways. When interviewed, people are asked questions regarding some particular aspect of sarma and plants which are used to prepare it. The questionnaire comprised two main parts: Part (i) consisted of demographic data which included age, gender, level of education, occupation, income, and religious belief. Part (ii) of the questionnaire asked for information about the local vernacular name of the plant, plant collection or delivery (wild, cultivated or from market), part(s) of the plant used, method of use (raw, preliminary treated), preservation (dry, fermented), method of wrapping, stuffing ingredients, the spices used, cooking method and specific taste.

Collected herbarium specimens are stored in the ethnobotanical voucher collection of one of the authors (AN) at the Department of Botany, Sofia University, together with photographic studies. Ethical guidelines drafted by the American Anthropological Association 
(AAA, 2012) were followed during the interviewing process and data documentation.

\section{Literature survey}

In total, thirty-five (35) sources, mostly published articles and books, were reviewed and analyzed. Data from field studies were supplemented with published ethnobotanical works for the study area and, increasingly in recent years, unpublished Masters and Ph.D. ethnobotanical theses, which are available online at the Thesis Center, Council of Higher Education (https://tez.yok.gov.tr/ UlusalTezMerkezi/istatistikler.jsp). They were summarized with references to folklore and gastronomic literature based on field investigations and papers published in international and national scholarly journals.

Taxonomic identification was conducted by the authors, and plant nomenclature followed Flora Europaea (Tutin et al., 1964-1980), the Angiosperm Phylogeny Group III system (Stevens, 2012), and The Plant List database (TPL, 2013).

\section{Data analysis}

All the collected ethnobotanical data were filed in a database (analytical table) and analyzed and summarized using Microsoft Excel 2016.

The collected information was analysed quantitatively using a synthetic index of relative frequency citation (RFC). This index shows the local importance of each species in terms of frequency of citation (FC, the number of informants mentioning the use of the species) divided by the total number of informants in the survey $(\mathrm{N})$.

$\mathrm{RFC}=\mathrm{FC} / \mathrm{N}(0<\mathrm{RFC}<1)$

RFC value varies from 0 (when nobody refers to a particular plant as being useful), to 1 (when all the informants mention it as useful) (Tardio and Pardo-DeSantayana, 2008).

This study is based both on data obtained from a survey of the literature (L) and data obtained from informants by means of semi-structured interviews, referred to here as a personal observation (PO). Consequently, two synthetic indices were calculated: $\mathrm{RFC}_{\mathrm{L}}$ which shows the importance of the species based on literature sources, where one source is equivalent to one citation (FC), and $\mathrm{RFC}_{\mathrm{PO}}$ which is based on field studies.

\section{RESULTS AND DISCUSSION}

\section{Quantitative results}

Seventy-three (73) plant taxa are recorded in this study. The detailed list of plants resulting from our observations and a review of the literature, is presented in Table 1. The plants belong to thiry-nine (39) genera and twenty-two (22) families, mainly comprising members of Polygonaceae $(16 \%)$, Asteraceae (12\%), Malvaceae (11\%), Amaranthaceae $(8 \%)$, and Brassicaceae (7\%) (Fig. 1). Only four plant genera are monocots: Allium, Arum, Colocasia and Smilax. The largest number of taxa was recorded for the genera Rumex (11), Salvia (5), Beta and Malva, (4), and Alcea, Arum, Brassica, Morus and Plantago (3). Of these taxa, most were herbaceous plants $(63,84.9 \%)$, whereas trees (8) and shrubs (2) were mostly members of Moraceae, Betulaceae, Rosaceae, Fabaceae and Malvaceae, and two species were represented by lianas (Smilax and Vitis). The list predominantly contained wild species, (51), followed by cultivated (20) and semi-domesticated species (2). Of the recorded species, only Smilax excelsa, a climbing plant, is evergreen.

Based on index analyses, $\mathrm{RFC}_{\mathrm{L}}$ ranges from 0.3 to 0.26 , and reveals the cultural importance of the following taxa: Rumex crispus (0.26), Rumex patientia (0.23), Cydonia oblonga (0.14), Rumex conglomeratus (0.14), Trachystemon orientalis (0.14), Plantago major ssp. major (0.11), Rumex tuberosus (0.11), Vitis vinifera (0.11). About 16 of the identified plants are based on data collected at interviews. The highest $\mathrm{RFC}_{\mathrm{PO}}$ is recorded for Malva neglecta (0.78), Rumex patientia (0.67) and Trachystemon orientalis $(0.35)$.

\section{The diversity of plants used for Sarma}

Fourteen species were found to be used in the form of vegetable leaves for sarma in the Balkans, but not in Turkey. Some of these species are used in mountainous rural areas, and include early spring plants, such as Primula veris (Albania), Allium ursinum (Bulgaria) and shrubs of certain Rubus and Ribes species (Bosnia and Herzegovina, Romania). Others are alternative cultivated plants, such as Atriplex hortensis, A. rosea, Vicia faba, Brassica oleracea var. gongylodes (Bulgaria), Vitis labrusca and Solanum tuberosum

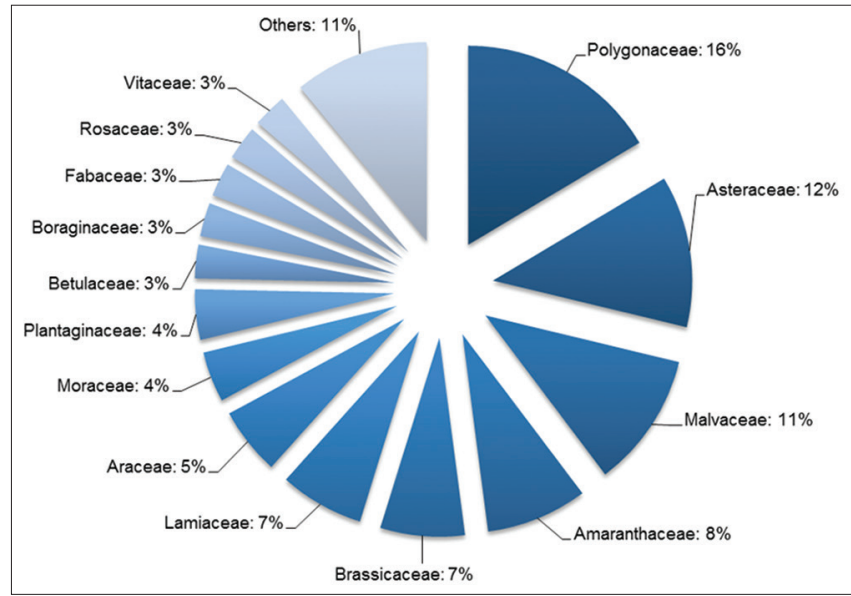

Fig 1. Systematic structure of plant families used. 


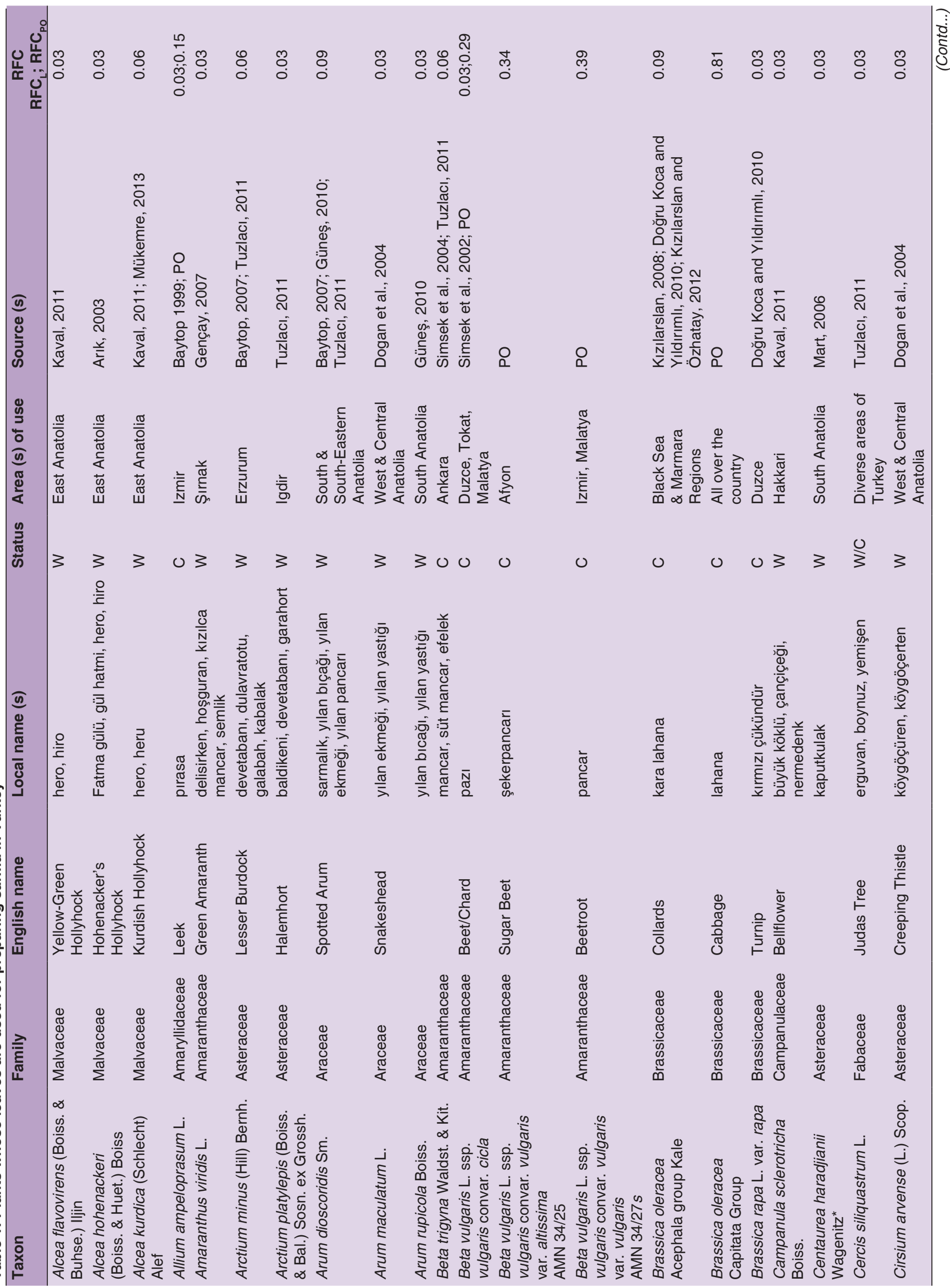




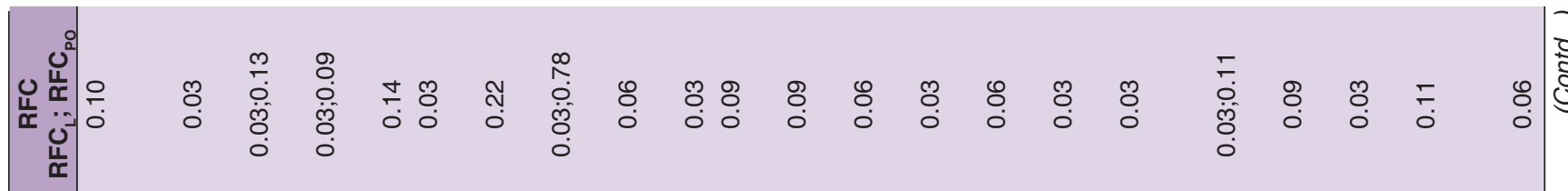

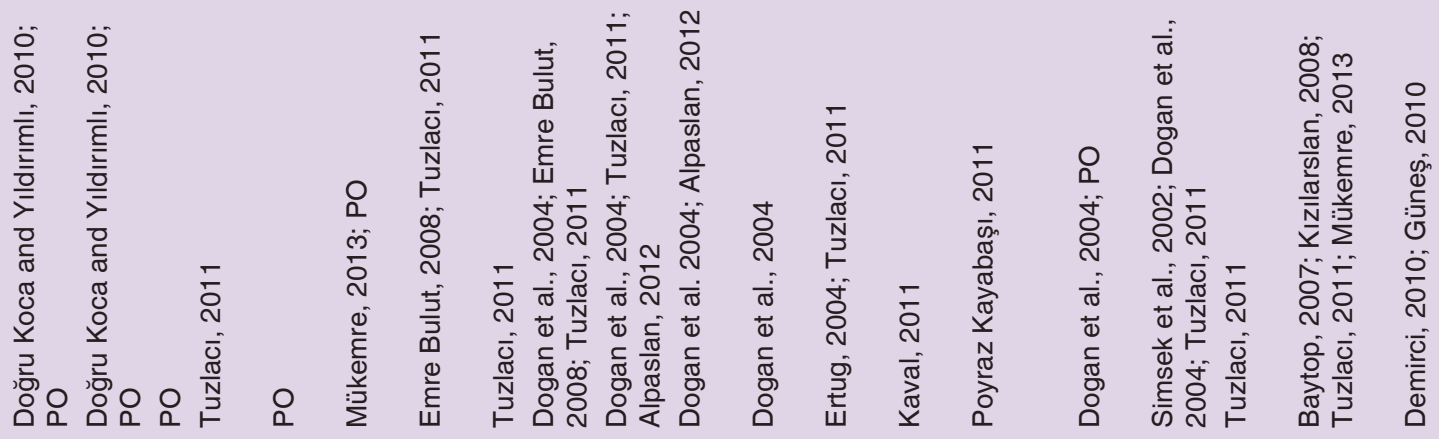

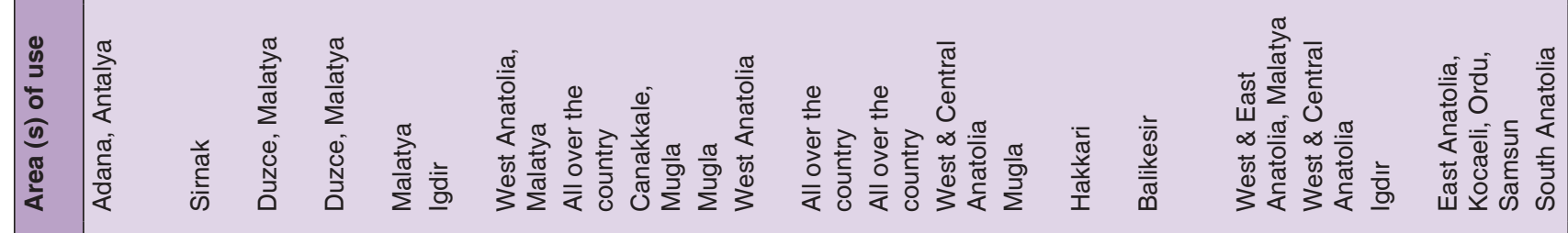

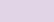<smiles>[AlH][AlH2]</smiles> 


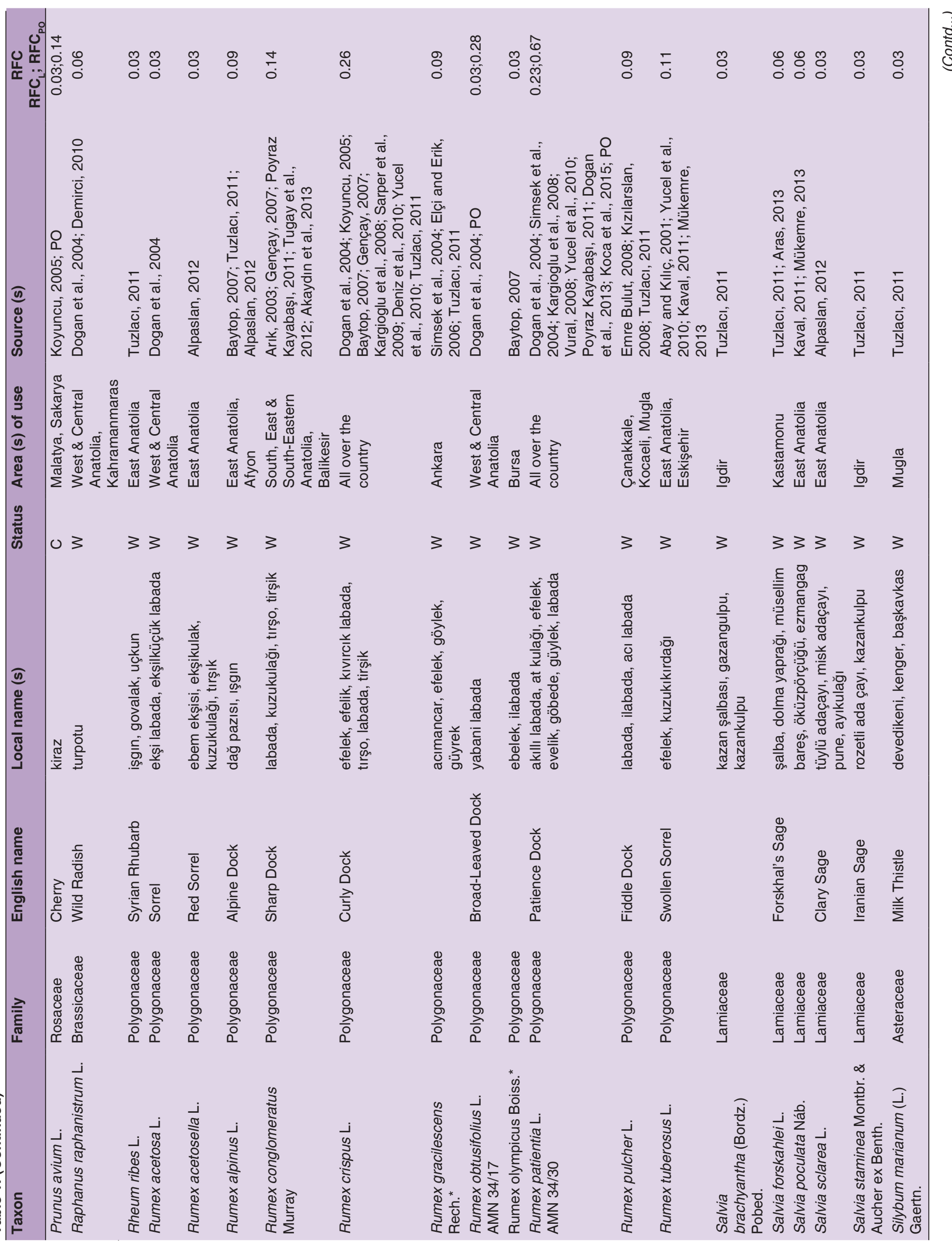




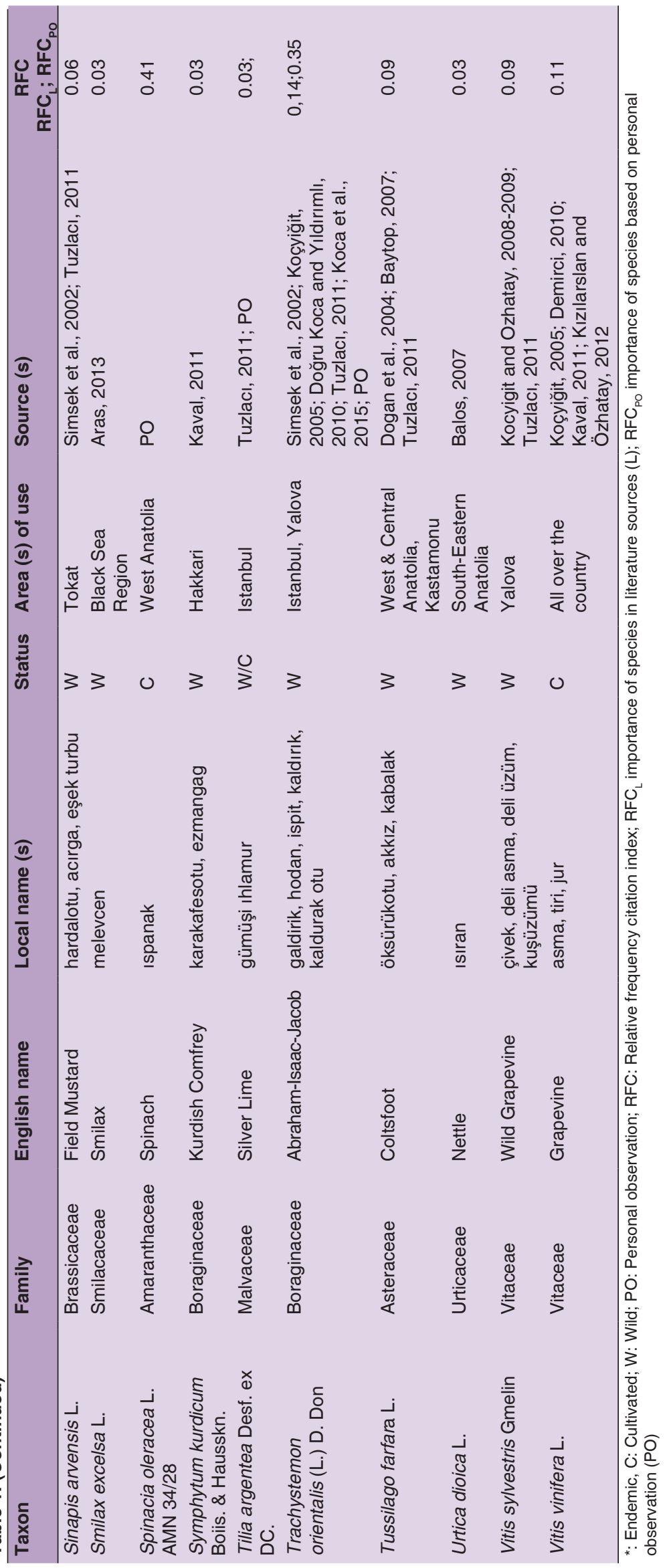


(Albania), whereas other species, such as Caltha palustris (Romania), are native to marshes, fens, ditches and wet woodland. In Turkey, wild edible greens are predominantly used, whereas leaves from cultivated plants tend to be used in other Balkan regions. Invasive and newly introduced species are little used in modern culinary sarma practices, although in Turkey, Colocasia esculenta is used, which is not used in other Balkan countries, and Reynoutria japonica is used in Romania (Dogan et al., 2015).

The use of leaves of three endemic species was recorded: Centaurea haradjianii (South Anatolia), Rumex gracilescens (Central Anatolia), and R. olympicus (Northwestern Anatolia). These species are very variable in terms of leaf morphology, and their leaves thus resembled those of other species of the same genus, which have also been traditionally used. The use of these species is relatively rare, expecially in conjunction with common widely used species. They are present as well-developed populations, and thus, their conservation status is not compromised by their use as food plants. The identification of Rumex gracilescens and R. olympicus based on The Plant List is taxonomically problematic. These endemic species are included in the lists of rare and endangered species in The Red Data Book of Turkish Plants (Ekim et al., 2000): C. haradjianii (VU, vulnerable), R. gracilescens (LR/ $\mathrm{nt}$, lower risk, near threatened), and R. olympicus (DD, data deficient). Based on our data for anthropogenic threats, and in order to evaluate the importance of the former two species, protection measures might be necessary. No other species recorded in this study is classified as a rare and protected species.

Of the cited plants, grapevine (fresh or in brine) and cabbage are widely used species, together with beet, dock, sorrel, horseradish, lime tree, bean, and spinach (Fig. 2). Most of the documented wild and cultivated plants are already well known edible plants used for preparing salad, soup or main meals and pies in local culinary outlets in the study area.

Sarma made from leek is part of the traditional cuisine of only some areas of Turkey, such as Western Anatolia. In contrast to other types of sarma, those prepared from leek (Allium ampeloprasum) are triangular in shape (Fig. 2). The common types of sarma made in Turkey are mostly long and cigar-shaped. In addition to triangular leek sarma, rolled leek leaves can also be used to prepare leek dolma (DurluOzkaya and Kizilkaya, 2009).

Ten of the established plants are sold as edible greens on the open market: Cabbage, grapevine, lime, beet, sorrel, common mallow, nettles, leeks and lettuce (Dogan et al., 2013; Dogan and Nedelcheva, 2015). Grapevine leaves (fresh or in brine) are sold especially for sarma preparation and are grouped together for easy sale and use, and to preserve the shape and size of the leaf blade (Fig. 2). The plants used for sarma in open markets are mostly cultivated

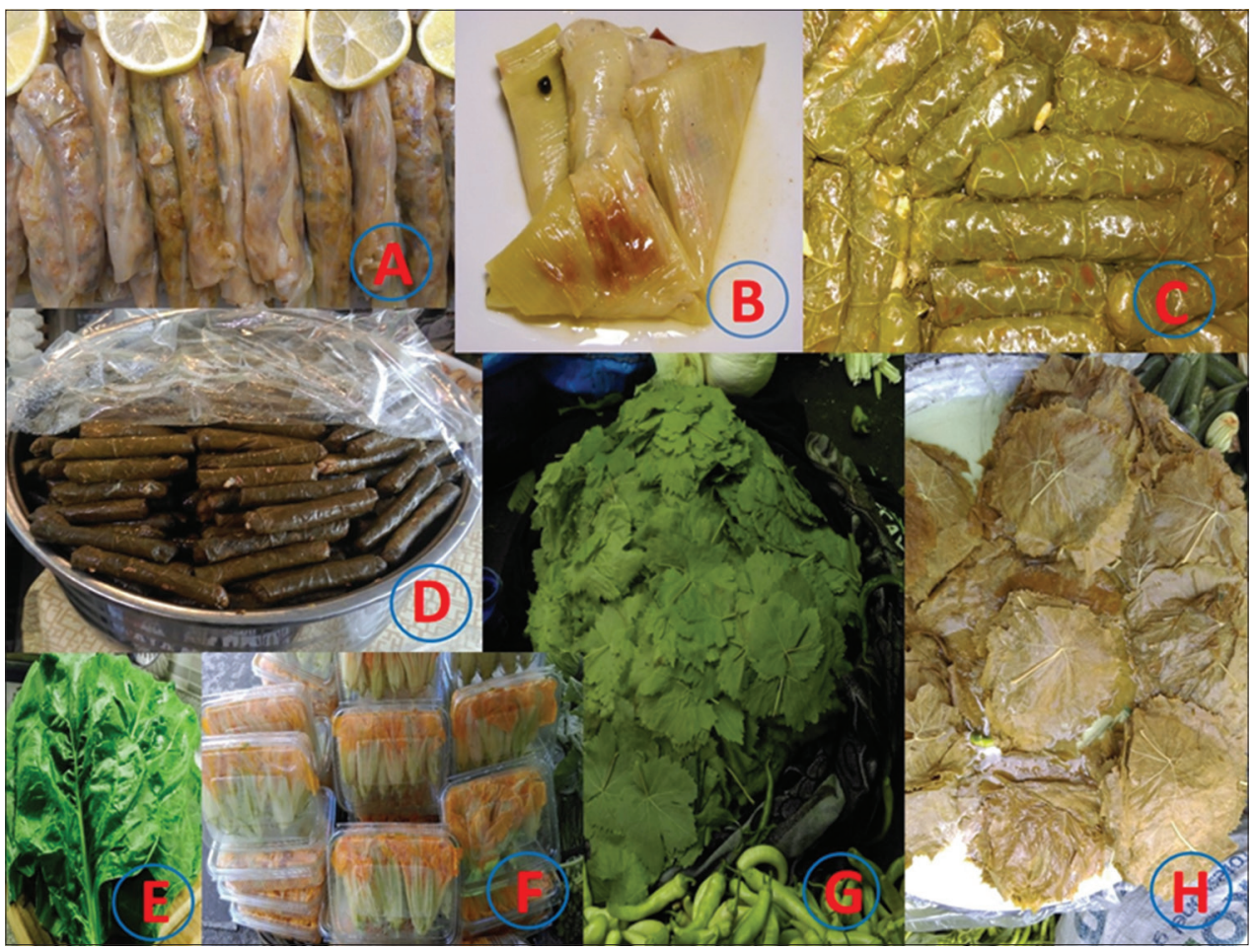

Fig 2. Some sarma samples; leaves and flowers for sarma in an open market in Turkey. A: Cabbage, B: Leek, C: Collards, D: Grapevine, E: Beet leaves, F: Zucchini flowers, G: Fresh grapevine leaves H: Grapevine leaves in brine. 
species. The majority of the wild edible greens are collected individually and are used locally in different regions.

The leaves of some of the recorded species are also used for medicinal purposes such as home remedies, mostly as herbal teas. These species form more than $20 \%$ of the listed taxa and belong to the genera Salvia, Tussilago, Urtica, Plantago, Primula, Rumex and Symphytum.

\section{Tradition vs the modern era in the selection of plant leaves for sarma}

Colocasia esculenta (taro, elephant ear or cocoyam) is a new root crop of southern provinces of Turkey and is grown for its edible corms (the root vegetables) $\left(\mathrm{RFC}_{\mathrm{PO}}(0.10)\right)$. Taro is also used as an ornamental plant. Colocasia esculenta is a novel sarma plant, which has been introduced into cuisine within the last decade, following its introduction to Turkey (Sen et al., 2001; Matthews, 2006). Fresh taro leaves are poisonous (attributed to the presence of a specific enzyme (protease) that is bound to crystals of calcium oxalate that occur as sharp, needle-like raphides), and this toxicity is reduced by cooking or soaking the leaves for several hours before they can be safely consumed. Taro leaves contain high concentrations of vitamins $\mathrm{A}$ and $\mathrm{C}$ and are a better source of protein than the roots. The leaves have a large, heart-shaped blade, with a tender-firm and succulent texture. One of the problems in using taro leaves is their acidity; however, cultivars of very low acidity are grown in Turkey, and thus, no special cooking techniques are required to reduce this. In many recipes, the leaves are rolled tightly, tied in a knot, and then simmered in coconut, red chili, tamarind, coriander and garlic. In the Philippines, the petioles and blades of young leaves are commonly used to prepare pinangat (a leaf packet), or fresh young blades are wrapped and tied around fish or shrimp paste, and are then cooked in coconut milk (Matthews et al., 2012). These leaf properties, probably together with the rapid exchange of information, has led to the incorporation of this new plant into traditional Ottoman cuisine. This extends our knowledge of the use of leaves, since the use of taro leaves in cuisine has not previously been recorded for the Eastern Mediterranean (Ramanatha et al., 2010; Matthews et al., 2012).

Modern science and the current requirements for Food Safety questions the use of some plant species for food. Recently, plants that contain pyrrolizidine alkaloids (PAs) have been brought into question. These are represented in this study by members of the Asteraceae, Boraginaceae and some Fabaceae. Data suggest that ingestion of PAs as a tea, or as a dish of butterbur (Petasites bybridus) and coltsfoot (Tussilago farfara), as served according to a traditional recipe, can lead to serious hepatic dysfunction and at high doses, PAs can lead to fatal liver failure (EFSA, 2011). This poses challenges to the traditional use of these plants as food, and more detailed information about their potential harm needs to be made available, together with the increased regulation of wild products currently readily available on the open market (Nedelcheva et al., 2015).

Some species are common members of the urban flora, including Tilia spp., Morus spp., Cercis siliquastrum, Vitis spp., Pelargonium quercetorum and Colocasia esculenta. Plants are perceived as sources of multivalent resources and their continued use represents a national way of thinking. Conversely, the preservation and development of TK present new considerations. For example, urban and industrial environments contain plants that grow in polluted air and soil, and thefore, the collection of leaves from such habitats is not safe, and this, in turn, presents problems that affect both wild ruderal and weed species.

The collection, marketing and use of some plants today highlight issues related to the response of natural habitats to human activity. Some species occur in disturbed areas, such as roadsides and pastures, but also in degraded forests. Since plants are often widely distributed and may grow in areas that, owing to their ruderal nature, are subject to anthropogenic agents, eating such plants may pose a risk. Considering that plants are widely used by local inhabitants as a fresh and dried food source, as well as for medicine, the importance of washing the plant before use is clear. A study of the heavy metal content of Malva sylvestris sold as an edible green in the local markets of Izmir (Turkey) showed that these plants were mostly collected from low-risk areas (Unver et al., 2015); however, there remains a need for vigilance and strict control as current anthropogenic influences establish new rules for the use of traditionally used plants.

In some cases, toxic plants are used following preliminary treatment of their leaves. Such plants include Arum, Convolvulus, Tussilago and Smilax species. The TK relating to their toxicity is reflected in the availability of detailed descriptions of pre-treatment and cooking methods (Dogan et al., 2015).

According to Table 1, the greatest diversity of plants used for types of sarma is consumed in Western Anatolia (in Izmir and its surroundings, e.g., leaves of Allium ampeloprasum, Beta vulgaris, Lactuca sativa, Morus rubra, Phaseolus vulgaris, Rumex obtusifolius, and Spinacia oleracea) and in Eastern Anatolia, especially in Malatya and its surroundings (e.g., leaves of Beta vulgaris, Cydonia oblonga, Lactuca sativa, Phaseolus vulgaris, and Prunus avium).

\section{Plant use categories}

Most notably, the rhizomes, flowering branches, petioles and leaves of Trachystemon orientalis, which is mostly 
distributed throughout Northern Anatolia, are very commonly consumed as vegetables in different parts of the Black Sea Region $\left(\operatorname{RFC}_{\mathrm{L}}(0.14)\right.$ and $\left.\mathrm{RFC}_{\mathrm{PO}}(0.35)\right)$. The stems and rhizomes are fried or boiled in water with onions and eggs and the roots and the petioles are used for making pickles. In addition, its sarma is widely consumed by the local people (Ergen Akcin et al., 2004; Dogan et al., 2015; Koca et al., 2015). In areas where it occurs naturally, it is known under various names, including acı hodan, balıkotu, burğı, çiçeklimancar, doğu hodanı, galdirek, hodan, 1spıt, kaldırık, kaldırayak, kaldirak, kaldirek, kaldirik, somara, tomara, tomari and zilbit. However, Borago officinalis L. (Boraginaceae) is also called "hodan". Due to this similarity, this plant is erroneously mentioned as a sarma plant on the internet. Another possible reason may be that various unscientific sources (including internet web sites) may refer to Trachystemon orientalis (L.) G. Don. by its synonym Borago orientalis $\mathrm{L}$. and is thus mistaken with Borago officinalis L. (as accepted in the Flora Europaea). Although there are no reports of this plant being used for sarma in Turkey, there are many reports for the use of T. orientalis (Baytop, 1984; Simsek et al., 2002; Ergen Akcin et al., 2004; Kocyigit, 2005; Dogru Koca and Yildirimli, 2010; Dogan et al., 2015; Koca et al., 2015).

The horse chestnut, Aesculus bippocastanum L., is an ornamental tree species that is naturally distributed throughout the Balkans and is commonly planted in parks, gardens and roadsides, because of its beautiful flowers and foliage. On many websites referring to this tree, its use as leaf sarma during Ottoman times is described, as well as its current use; however, no cook books or scientific reports confirm this.

\section{Sarma and Dolma}

Only two plants from Turkey are used for preparing both sarma and dolma: Leek and artichoke (Cynara scolymus L.). Artichoke dolma is very famous in Turkey, as opposed to artichoke sarma, which is mostly unknown. This sarma is typical mostly for the area of Izmir.

In addition to the leaf sarmas mentioned above, dolmas made with zucchini blossoms are commonly consumed in the Aegean region. Cretan migrants settled in this region and zucchini blossom is sold in the open markets of Izmir (Fig. 2). As with regular sarma, these dolmas are also stuffed with cheese (Berik and Varlik, 2009; Hancerli, 2011; Altay and Karakan, 2012; Karaca et al., 2015). Owing to the delicacy of the flowers, the preparation of zucchini blossom dolmas is comparatively more demanding.

Melon dolma occupied an important place in the Ottoman palace kitchen during the fifteenth and sixteenth centuries, although it is no longer a common meal in Turkish cuisine.
Apple and quince dolmas are examples of fruit dolmas that currently exist.

Regional variations exist for the preparation of stuffing for sarmas and dolmas in Turkish cuisine. The most striking example is Tokat sarma, whose stuffing is prepared with dry broad (fava) beans (Akin and Lambraki, 2003).

Despite the importance of plants in the preparation of traditional sarma, only three species have names that reflect their use: Arum dioscoridis (sarmahk, yılan bıçağı, y1lan ekmeği, y1lan pancar1), Onopordum illyricum (deli kenger, dolma kenkeri, eșek dikeni) and Salvia forskablei (şalba, dolma yaprağ1, müsellim). These, however, are not plants that are most frequently used today, but each has more than one folk name.

\section{CONCLUSIONS}

Turkey is home to the greatest number of diverse species of edible greens used for sarma and this diversity reflects that found both in the region and in the Balkans. The traditional botanical folk knowledge for preparing sarma is well preserved, although contemporary methods of exchanging information, and the movement of people impact on traditional practices and the introduction of new plant products. Knowledge of these methods and trends is essential for the sustainable use and conservation of biodiversity and the control and use of safe foods and herbal products.

\section{Authors' Contributions}

All authors YD, AN and AP contributed equally to this work.

\section{REFERENCES}

AAA. 2012. American Anthropological Association Statement on Ethics: Principles of Professional Responsibility. Available from: http://www.aaanet.org/profdev/ethics/. [Last accessed on 2017 March 15].

Abay, G. and A. Kıllıc. 2001. Pürenbeleni ve Yaniktepe (Mersin) yörelerindeki bazi bitkilerin yöresel adlari ve etnobotanik özellikleri. Ot Sistematik Bot. Derg. 8(2): 97-104.

Akaydın, G., I. Şimşek, Z. C. Arıtuluk and E. Yeşilada. 2013. An ethnobotanical survey in selected towns of the Mediterranean subregion (Turkey). Turk. J. Biol. 37: 230-242.

Akin, E. and M. Lambraki. 2003. Aynı Sofrada İki Ülke Türk-Yunan Mutfağı, Türkiye İş Bankası Kültür Yayını, Istanbul.

Alpaslan, Z. 2012. The Ethnobotanical Properties of Ergan Mountain (Erzincan). M.Sc. Thesis, Erzincan University, Erzincan.

Altay, V. and F. Karakan. 2012. An ethnobotanical study about plants in Tayfur Ata Sokmen Campus (Antakya-Hatay) and its environs. Black Sea J. Sci. 2(7): 13-28.

Aras, N. 2013. 'Sarma' and 'Dolma': Rolled and stuffed dishes as therapy tools for the anatolian women in the kitchen. In: Proceedings of the Oxford Symposium on Food and Cookery 
"Wrapped and Stuffed Foods", Publisher Totnes, UK, pp. 57-67.

Arık, M. 2003. Useful Plants of Korkut Town (Muş) and Its Villages. M.Sc. Thesis, Yüzüncü Yıl University, Van.

Balos, M. M. 2007. The Flora and Ethnobotany of the Region Between Zeytinbahçe and Akarçay (Birecik). M.Sc. Thesis, Harran University, Şanlıurfa.

Basaran, V. 2009. A union of taste and toil: Stuffed vegetables. Skylife. 4: 125-129.

Baytop, T. 1984. Turkiye'de Bitkiler Ile Tedavi, Istanbul Universitesi Eczacilik Fakültesi Yayinlari, Istanbul.

Baytop, T. 1999. Turkiye'de Bitkilerle Tedavi, Nobel Tip Kitabevleri, Istanbul.

Baytop, T. 2007. Turkish Dictionary of Plant Names, Türk Dil Kurumu Yayınları, Ankara.

Berik, N. and C. Varlik. 2009. Ege Bölgesi'nden sağlıklı lezzetler: suteresi soslu sardalya ve kabak çiçeği dolması. In: "II Geleneksel Gıdalar Sempozyumu”, Publisher Yüzüncü Yıl University, Van, Turkey, pp. 554-556.

Bilgin, A. 2014. Refined Tastes in a Refined Place: Eating Habits in the Ottoman Palace During the $15^{\text {th }}$-17th Centuries. Available from: http://www.turkish-cuisine.org. [Last accessed on 2017 May 2].

Demirci, S. 2010. Ethnobotanical Study in Andirin (Kahramanmaras) District. M.Sc. Thesis, Istanbul University, Istanbul.

Deniz, L., A. Serteser and M. Kargığlu. 2010. Local names and ethnobotanical features of some plants in Usak University (Usak) and its near vicinity. Afyon Kocatepe Univ. J. Sci. Eng. 10(1): 57-72.

Dogan, Y. 2012. Traditionally used wild edible greens in the Aegean region of Turkey. Acta Soc. Bot. Pol. 81(4): 329-341.

Dogan, Y. and A. Nedelcheva. 2015. Wild plants from open markets on both sides of the Bulgarian-Turkish border. Indian J. Tradit. Knowl. 14(3): 351-358.

Dogan, Y. and I. Ugulu. 2013. Medicinal plants used for gastrointestinal orders in some districts of Izmir Province, Turkey. Stud. Ethno Med. 7: 149-162.

Dogan, Y., S. Baslar, G. Ay and H. H. Mert. 2004. The use of wild edible plants in Western and Central Anatolia (Turkey). Econ. Bot. 58(4): 684-690.

Dogan, Y., S. Baslar, H. H. Mert and G. Ay. 2003. Plants used as natural dye sources in Turkey. Econ. Bot. 57(4): 442-453.

Dogan, Y., A. M. Nedelcheva, D. Obratov-Petkovic and I. M. Padure. 2008. Plants used in traditional handicrafts in several Balkan countries. Indian J. Tradit. Knowl. 7: 157-161.

Dogan, Y., A. Nedelcheva, L. Luczaj, C. Dragulescu, G. Stefkov, A. Maglajlic, J. Ferrier, N. Papp, A. Hajdari, B. Mustafa, Z. DajićStevanović and A. Pieroni. 2015. Of the importance of a leaf: The ethnobotany of sarma in Turkey and the Balkans. J. Ethnobiol. Ethnomed. 11: 6.

Dogan, Y., I. Ugulu and N. Durkan. 2013. Wild edible plants sold in the local markets of Izmir, Turkey. Pak. J. Bot. 45(S1): 177-184.

Doğru, K. A. and S. Yıldırımlı. 2010. Ethnobotanical properties of Akçakoca district in Düzce (Turkey). Hacettepe J. Biol. Chem. 38(1): 63-69.

Durlu-Ozkaya, F. and O. Kizilkaya. 2009. Dolmalar ve Türk mutfaği ile Yunan mutfağindaki yeri. In: "Il Geleneksel Gıdalar Sempozyumu", Publisher Yüzüncü Yıl University, Van, Turkey, pp. 511-515.

EFSA. 2011. Panel on contaminants in the food chain (CONTAM); Scientific opinion on pyrrolizidine alkaloids in food and feed. EFSA J. 9(11): 2406.
Ekim, T., M. Koyuncu, M. Vural, H. Duman, Z. Aytaç and N. Adiguzel. 2000. Türkiye Bitkileri Kırmızı Kitabı. Türkiye Tabiatını Koruma Derneği, Ankara.

Elçi, B. and S. Erik. 2006. Ethnobotanical properties of Güdül (Ankara) and near environs. Hacettepe Univ. J. Fac. Pharm. 26(2): 57-64.

Emre, B. G. 2008. Ethnobotanical Investigations in Bayramiç (Çanakkale). M.Sc. Thesis, Marmara University, Istanbul.

Ergen, A. O., N. Kandemir and Y. Akcin. 2004. A morphological and anatomical study on a medicinal and edible plant Trachystemon orientalis (L.) G. Don (Boraginaceae) in the Black Sea region. Turk. J. Bot. 28: 435-442.

Ertug, F. 2004. Wild edible plants of the Bodrum area (Mugla, Turkey). Turk. J. Bot. 28: 161-174.

Fragner, B. 1994. From the Caucasus to the roof of the world: A culinary adventure. In: Zubaida, S., R. Tapper (Eds.), A Taste of Thyme: Culinary Cultures of the Middle East, B. Tauris, London and New York, pp. 49-62.

Gençay, F. 2007. Ethnobotanical Aspects of Cizre (Şırnak). M.Sc. Thesis, Yüzüncü Yıl University, Van.

Güneş, S. 2010. Ethnobotanical Investigation on the Use of Plants in the Villages of Karaisali (Adana). M.Sc. Thesis, Niğde University, Niğde.

Hancerli, H. Y. 2011. Girit Mutfağının Çukurovadaki Izleri, Hançerli Fotoğrafçılık Ltd. Şti., Adana.

Karaca, O. B., O. Yıldırım and A. C. Çakıcı. 2015. Cretan food culture and its sustainability. J. Tour. Gastronomy Stud. 3(1): 3-13.

Kargioglu, M., S. Cenkci, A. Serteser, N. Evliyaoglu, M. Konuk, M. S. Kök and Y. Bagci. 2008. An ethnobotanical survey of InnerWest Anatolia, Turkey. Hum. Ecol. 36(5): 763-777.

Kargioglu, M., S. Cenkci, A. Serteser, M. Konuk and G. Vural. 2010. Traditional uses of wild plants in the Middle Aegean region of Turkey. Hum. Ecol. 38(3): 429-450.

Kaval, I. 2011. The Ethnobotany of Geçitli (Hakkari) and Its Vicinity. M.Sc. Thesis, Yüzüncü Yıl University, Van.

Kızılarslan, C. 2008. An Ethnobotanical Survey in the Southern Part of the Gulf of Izmit. M.Sc. Thesis, Istanbul University, Istanbul.

Kızılarslan, Ç. and N. Özhatay. 2012. An ethnobotanical study of the useful and edible plants of Izmit. Marmara Pharm. J. 16(3): 194-200.

Koca, I., I. Hasbay, S. Bostanci, V. A. Yilmaz and A. F. Koca. 2015. Some wild edible plants and their dietary fiber contents. Pak. J. Nut. 14(4): 188-194.

Koçyiğit, M. 2005. An Ethnobotanical Study in the Yalova Province. M.Sc. Thesis, Istanbul University, Istanbul.

Kocyigit, M. and N. Ozhatay. 2008-2009. The wild edible and miscellaneous useful plants in Yalova Province (Northwest Turkey). J. Fac. Pharm. Istanbul. 40: 19-29.

Koyuncu, O. 2005. Investigations of Floristic and Etnobotanical Aspects of Geyve (Sakarya) and its Environment. M.Sc. Thesis, Eskişehir Osmangazi University, Eskişehir.

Mart, S. 2006. An Ethnobotanical Investigation of the Natural Plants Using by Inhabitants in Bahçe and Hasanbeyli Districts of Osmaniye Province. M.Sc. Thesis, Çukurova University, Adana.

Matthews, P. 2006. Written records of taro in the Eastern Meditteranean. In: Proceedings of the Fourth International Congress of Ethnobotany (ICEB 2005), Publisher Zero Prod. Ltd. Istanbul, Turkey, pp. 419-426.

Matthews, P. J., E. M. G. Agoo, D. A. Tandang and D. A. Madulid. 2012. Ethnobotany and ecology of wild taro (Colocasia esculenta) in the Philippines: Implications for domestication and dispersal. In: Spriggs, M., D. Addison and P. J. Matthews (Eds.), 
Irrigated Taro (Colocasia esculenta) in the Indo-Pacific, Vol. 78. National Museum of Ethnology, Senri Ethnological Studies, Osaka, pp. 307-340.

Mükemre, M. 2013. Ethnobotanical Features of Konalga, Sırmalı, Dokuzdam Villages (Çatak/Van) and Their Vicinity. M.Sc. Thesis, Yüzüncü Yıl University, Van.

Nedelcheva, A. M., Y. Dogan, D. Obratov-Petkovic and I. M. Padure. 2011. The traditional use of plants for handicrafts in Southeastern Europe. Hum. Ecol. 39(6): 813-828.

Nedelcheva, A., N. Kostova and A. Sidjimov. 2015. Pyrrolizidine alkaloids in Tussilago farfara from Bulgaria. Biotechnol. Biotechnol. Equip. 29(S1): S1-S7.

Ozbucak, T. B., H. G. Kutbay and O. E. Akcin. 2006. The contribution of wild edible plants to human nutrition in the Black Sea region of Turkey. Ethnobot. Leaf. 10: 98-103.

Poyraz, K. N. 2011. The Ethnobotanical Examines in the Villages of Manyas and Manyas. M.Sc. Thesis, Balıkesir University, Balıkesir.

Ramanatha, R. V., P. J. Matthews, P. B. Eyzaguirre and D. Hunter (Eds.). 2010. The Global Diversity of Taro: Ethnobotany and Conservation. Bioversity International, Rome.

Sarper, F., G. Akaydin, I. Şimşek and E. Yeşilada. 2009. An ethnobotanical field survey in the Haymana district of Ankara Province in Turkey. Turk. J. Biol. 33(1): 79-88.

Savkay, T. 2000. Ottoman Cuisine (Osmanlı Mutfağı), Şekerbank T.A.Ş., İstanbul.

Sen, M., A. Akgul and M. Ozcan. 2001. Physical and chemical characteristics of taro [Colocasia esculenta (L.) Schott] corms and processing to chips and puree. Turk. J. Agric. For. 25: 427-432.

Simsek, I., F. Aytekin, E. Yesilada and S. Yildirimli. 2002. Anadolu'da halk arasinda bitkilerin kullaniliş amaçlari üzerinde etnobotanik bir çalişma. In: Başer, K. H. C. and N. Kırımer (Eds.), 14 Bitkisel İlaç Hammaddeleri Toplantısı Bildirileri, Eskisehir University, Eskişehir, pp. 434-457.
Simsek, I., F. Aytekin, E. Yesilada and S. Yildirimli. 2004. An ethnobotanical survey of the Beypazari, Ayas, and Güdül district towns of Ankara Province (Turkey). Econ. Bot. 58(4): 705-720.

Stevens, P. F. 2012. Angiosperm Phylogeny Website. Version 13. Available from: http://www.mobot.org/MOBOT/research/ APweb/. [Last accessed on 2017 May 2].

Tardio, J and M. Pardo-De-Santayana. 2008. Cultural importance indices: A comparative analysis based on the useful wild plants of Southern Cantabria (Northern Spain). Econ. Bot. 62: 24-39.

TPL. 2013. The Plant List. Available from: http://www.theplantlist.org/. [Last accessed on 2017 May 2].

Tugay, O., I. Bağcı, D. Ulukus, E. Ozer and M. A. Canbulat. 2012. Wild plants using as food of Kurucuova town (Beyşehir, Konya/ Turkey). Biol. Divers. Conserv. 5: 140-145.

Tutin, T. G., V. H. Heywood, N. A. Burge's, D. M. Moore, D. H. Valentine, S. M. Walters and D. A. Webb. 1964-1980. Flora Europaea, Cambridge University Press, Cambridge.

Tuzlacı, E. 2011. Wild Edibles and Herbal Dishes in Turkey, Alfa Yayınları, Istanbul.

Ugulu, I., S. Baslar, N. Yorek and Y. Dogan. 2009. The investigation and quantitative ethnobotanical evaluation of medicinal plants used around Izmir Province, Turkey. J. Med. Plants Res. 3(5): 345-367.

Unver, M. C., I. Ugulu, N. Durkan, S. Baslar and Y. Dogan. 2015. Heavy metal contents of Malva sylvestris sold as edible greens in the local markets of Izmir. Ekoloji. 24(96): 13-25.

Vural, G. 2008. Ethnobotanical Features Some of the Willd Plants on the Honaz Mountain and Its Environment. M.Sc. Thesis, Afyon Kocatepe University, Afyonkarahisar.

Yerasimos, M. 2002. 500 Years of Ottoman Cuisine (500 Yıllık Osmanlı Mutfağı), Boyut, Istanbul.

Yucel, E., F. Guney and E. Y. Sengun. 2010. The wild plants consumed as a food in Mihaliccik district (Eskisehir/Turkey) and consumption forms of these plants. Biol. Divers. Conserv. 3(3): 158-175. 